\title{
The Prospect of Nanoinsecticide in Controlling Citrus Aphids Aphis gossypii
}

\author{
Susi Wuryantini ${ }^{1 *}$, Harwanto ${ }^{1}$ \\ ${ }^{1}$ Indonesian Citrus and Subtropical Fruits Research Institute, Batu, East Java 65301, Indonesia \\ *Corresponding author. Email: susi_wur@yahoo.com
}

\begin{abstract}
Nanotechnology is utilized in various fields including agriculture, one of which is in the botanical insecticide formulation. The material used for the formulation of botanical insecticide nano emulsion was tobacco leaf, which was applied to the citrus aphids, Aphis gossypii. This study aimed to determine the effectiveness of botanical insecticide from tobacco leaves in the form of nano emulsion compared to crude extracts. The test was carried out at 4 concentration levels, $0.01 \%, 0.1 \%, 1 \%$ and $10 \%$ and was accompanied by control and two synthetic insecticides in the form of formulation, imidacloprid $0.05 \%$ and dimethoate $0.1 \%$. The results showed that nano emulsions were more effective than crude extracts. The effective concentrations were $1 \%$ and $10 \%$. The mortality at $1 \%$ and $10 \%$ concentrations of crude extract were $58 \%$ and $100 \%$, while the mortality of nano emulsiuons were $100 \%$ and $96 \%$ at 48 HAA, respectively. The mortality of nano emulsion was significantly different to the control and not significantly different to the two synthetic insecticides. The $\mathrm{LD}_{50}$ values of crude extract and nano emulsion were $0.73 \%$ and $0.14 \%$ and the $\mathrm{LD}_{90}$ values were $2.65 \%$ and $1.69 \%$ at 48 HAA, respectively. Thus, the tobacco botanical insecticide in nanoemulsion form was more effective than the crude extract, so that it could be used as a prospective controlling material against citrus aphids A. gossypii.
\end{abstract}

\section{Keywords: botanical insecticide, control of citrus aphids, nano emulsion, tobacco leaf}

\section{INTRODUCTION}

Citrus is one of the national superior commodities. Citrus farming can contribute to increase farmer's income. Along with the increase in people's knowledge and awareness of nutrition, it has also contributed to the development of citrus agribusiness. The development of citrus agribusiness in Indonesia has been increasing and encouraging. One of the supports was the free assistance program of one million seeds from the Indonesian Agency for Agricultural Research and Development through the Research Institute for Citrus and Subtropical Fruits (Balitjestro) in 2018. Several citrus production centre areas have increased their planting areas and even some regions have opened new areas for citrus agribusiness.

In citrus agribusiness, there are several obstacles that cause a decrease in the quantity and quality of production, one of which is the attack of pests and diseases. The main types of pest and disease of citrus that have been found in Indonesian citrus production centres consist of several groups. From the group of diseases, there are HLB caused by Liberibacter asiaticus, diplodia disease Botrydiplodia theobromae, Tristeza disease (Citrus Tristeza Virus), scab caused by the fungus of Spaceloma fawcetti, citrus cancer caused by the bacterium Xanthomonas axonopodis pv. Citri shooty mold by the fungus Capnodium citri; powdery mildew caused by the fungus Oidium tingitanium, etc. From the group of pests, there are citrus psyllid Diaphorina citri, aphids (Toxoptera citricidus, T. aurantia, Myzus persicae and Aphis gossypii), fruit flies (Bactrocera spp.), scale insect Aonidiella aurantia, Lepidosaphes beckii, Coccus viridis; citrus red mites Panonychus citri, citrus rust mite Phylocoptruta oleivora, citrus silver mites Polyphagotarsonemus latus, etc. [1].

Pest control that is commonly practiced by farmers is using synthetic pesticides. If the application of synthetic pesticides is not properly done, this would cause negative effects on consumers and the environment as well [2]. Efforts to reduce chemical control are by implementing environmentally friendly controls, one of which is by using botanical pesticides. Many sources of plant material can be used as botanical pesticides, especially insecticides. Bioactive compounds found in plants could act as insecticides. In nature, there are at least 100 plant species that have been identified as botanical insecticides sources in order to control insect pests [3]. The use of botanical pesticides which is now widely developed is started from Ancient Egypt, China, Greece and India [4, 5] and now this technique has spread almost to all over the world including Indonesia. There are some plants that have been used as botanical insecticides to control citrus pests including neem, marigold, soursop, jatropha, tobacco and chrysanthemum [6-10].

Botanical pesticides are natural chemicals extracted from plants. These products are available as an alternative to the widely used synthetic pesticides [11]. Botanical insecticide from Tithonia diversifolia and Vernonia amygdalina [12] and from Piper sarmentosum leaf extract can control Colletrotrichum on mangoes [13]. Rhizome extracts of Curcuma xanthorrhiza, Zingiber montanum, $C$. 
longa and Z. zerumbet have been known to have quite high effectiveness as acaricide [14]. Citrus plant Citrus sinensis, cocoa Theobroma cacao, $T$. diversifolia, cashew Anacardium occidentale and sunflowers are used to control termites, Macrotermus bellicosus in Tanzania [15]. Extracts of Calotropis procera, datura or jimson weed (Datura stamonium), neem (Azadirachta indica) and tobacco (Nicotiana tabacum) have been used to control Plutella xylostella larvae on cabbage cultivations [16].

The application of botanical insecticides is more directed for consumer safety and the environment, in relation to health problems. The use of botanical pesticides in the current era is widely developed for food products that lead to organic, because it is known that botanical pesticides have a much lower risk compared to synthetic pesticides. In addition, the use of botanical insecticides also leads more to the use of local wisdom practices [2].

In its development, the use of botanical insecticides is not only in the form of water extracts or crude extracts with certain solvents, but also it has led and followed the development of technology by utilizing nanotechnology. In this era, nanotechnology has been used in various fields such as medicine, electronics, catalysis, remediation and agriculture. In the field of agriculture, nanotechnology provides new tools in the form of biological fertilizers, nano pesticides and nano sensors for conventional agricultural practices [17]. Nanoinsecticide formula is made to increase the effectiveness of botanical insecticides. Nano emulsion and nanoencapsulation are one of the most widely used and effective nano pesticide techniques for controlling plant diseases $[18,19]$.

Nano emulsion as a non-equilibrium system presents properties that depend not only on the composition of formulation but also on the method of making formulation and optimizing formulation stability [20]. Nano-technology for pesticides, especially botanical pesticides, is used to improve the botanical pesticide effectiveness and to reduce the negative effect of the use of synthetic pesticides on the environment and humans. Nano pesticides provide pesticide properties or formulations of active ingredients of pesticides in the form of nanoparticles. This nanostructure has shown slow degradation and release of controlled active ingredients for a long time. The properties of the nano pesticides as mentioned above make it environmentally friendly [17]. In this study, the experiment was conducted to compare the effectiveness of conventional botanical insecticides and in the form of nano emulsion.

\subsection{Materials and Methods}

The study was conducted in the entomology laboratory and the screen house of the Indonesian Citrus and Subtropical Fruits Research Institute (ICSFRI) in April to August 2017. This study used a Completely Randomized Design (CRD) with 7 treatments and 4 replications. This study included control and comparative treatments which were $0.05 \%$ imidacloprid and $0.1 \%$ dimethoate insecticides based on their formulation. Citrus aphids, A. gossypii used were collected from ICSFRI citrus orchard that were mass reared to obtain uniform population. The tobacco extracts used were extracted from tobacco shoots collected from Madura.

\subsubsection{Botanical insecticide extractions}

Botanical insecticide extracts of tobacco was done by maceration method. The tobacco leaves were cut and then milled into coarse powder using a blender. The powder was dissolved in methanol at a ratio of 1: $2(\mathrm{v} / \mathrm{v})$ for $24 \mathrm{hr}$ at room temperature [21]. The use of methanol solvents in this method was based on the previous studies [8]. The results of the marinade were then filtered to get the filtrate. The filtrate then was evaporated using a rotary evaporator to get crude extract. The crude extract was used as main ingredient in this study.

\subsubsection{Processing of botanical insecticide nano emulsion}

The processing of nano emulsion of botanical insecticide was carried out at the Nanotechnology Laboratory of the Post-Harvest Agricultural Research and Development Centre, Bogor. The process of transforming particles into nano-sized particles was done using high energy Ultraturrax. This was done based on optimizations that have been conducted before. Nano emulsion was made by extracting tobacco shoots, and then added with an emulsifier and distilled water, then processed with Ultraturrax at 11,000 rpm for $15 \mathrm{~min}$. The crude extract and nano emulsion formulations then were analysed for Particle size measurements using Particle Size Analyzer (PSA), the polydispersity index and potential Zeta.

\subsubsection{Preparation of test insects}

The insects used were citrus aphid on a second to third instar. Mass rearing was conducted on a host of citrus plants that were sprouting. The adults of A. gossypii were infested on the buds of citrus plants. The next offspring emerged were awaited until they entered instar 2 to 3 for the testing.

\subsubsection{Bioassay of botanical insecticide}

The botanical insecticide tested was tobacco leaf extract in the form of crude extract and nano emulsion. Each was diluted according to the treatment concentration of $0.01 \%$, $0.1 \%, 1 \%, 10 \%$ and control (without tobacco leaf extract). As a comparison, $0.05 \%$ imidacloprid and $0.1 \%$ dimethoate (based on formulation) were applied. The test insects were prepared by infesting 20 insects per shoot onto citrus shoot. Insects have been sprayed with crude extract emulsions, nano emulsions, two synthetic insecticides and control. Observations were conducted at 2, 4, 24, 48, 72, 96, 120 and 
$144 \mathrm{hr}$ after application (HAA). The parameter observed was the mortality of the tested insects, by counting the number of the dead and living insects on each treatment.

\subsubsection{Data analysis}

Data on the number of dead insects in each treatment were calculated by the percentage of death (mortality). The mortality data will be analysed by using a Completely Randomized Design (CRD) to determine the effectiveness of each treatment. Furthermore, Probit analysis was used to determine the Lethal Dose $\left(\mathrm{LD}_{50}\right)$ and $\mathrm{LD}_{90}$ values which were analysed by using the Minitab 16 program.

\subsection{Our Contribution}

This paper provides information on the potential of tobacco leaves crude extract as a botanical insecticide to control citrus aphid, A. gossypii. In addition, the information presented is about the use of nanotechnology in making botanical insecticide formulations that can improve the efficacy of formulation. This study also contributes in searching for an alternative insect control strategy which is environmentally friendly in order to reduce and minimize the negative impacts caused by excessive and improper use of synthetic insecticides. The results of this research are promising, and further research is needed to determine the appropriate concentration for each target pest.

\subsection{Paper Structure}

This paper is structured as follows: Introduction part that explains the potential and economic values of citrus plants, constraints experienced in citrus cultivation, management of citrus pests and diseases that commonly use synthetic pesticides and efforts to find potential botanical insecticides as well as the development of botanical insecticide formulations. The next section describes botanical insecticide extraction, the process of transformation to nano emulsion and the preparation and treatment of tested insects. The subsequent section explains the test results that show the effectiveness of nano emulsion of botanical insecticide against target pests and the last part is the conclusions and recommendations for further research.

\section{RESULTS AND DISCUSSION}

The testing results of the effectiveness of tobacco crude extracts in the form of crude extracts and nano emulsions were presented on Figure 1 and 2.

Based on these results, it can be stated that the tobacco crude extract was effective in controlling citrus aphids at concentrations of $1 \%$ and $10 \%$. At $1 \%$ concentration, the

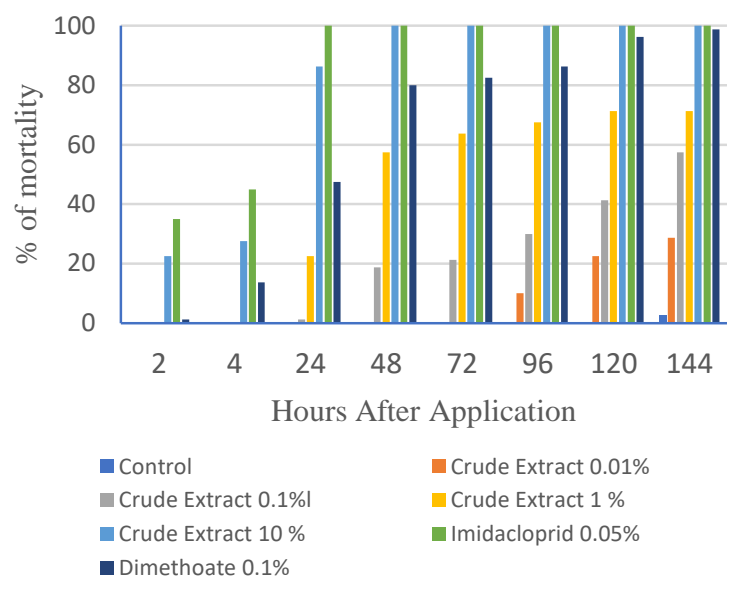

Figure 1 The mortality effect of tobacco crude extract on citrus aphids Aphis gossypii

mortality effect was $58 \%$ at 48 HAA. The mortality continued to increase until the end of observation at 144 HAA with $71 \%$ mortality, which was significantly different with control and the treatments of $0.01 \%$ and $0.1 \%$ concentrations. However, the percent of mortality of $1 \%$ concentration of tobacco crude extract was lower than treatment at $10 \%$ and two synthetic insecticides.

The mortality of tobacco crude extract at $10 \%$ concentration at $24 \mathrm{HAA}$ was $86 \%$. This mortality was higher than dimethoate treatment but lower than imidacloprid treatment. The $100 \%$ mortality was reached at 48 HAA and showed no significantly different with imidacloprid and dimethoate treatments but showed significantly different with other lower tobacco crude extract concentrations and control.

The tobacco botanical insecticide in nano emulsion formulation caused mortality on citrus aphids at lower concentrations. Nano emulsion at $1 \%$ concentration caused 94\% mortality of aphids at 24 HAA and showed significantly different with other treatments except to treatments of nano emulsion at $10 \%$ and imidacloprid which caused $96 \%$ and $100 \%$ mortality, respectively.

The results were consistent until the observations at 96 HAA, where the mortality of aphids at the concentrations of $1 \%$ and $10 \%$ were not significantly different with imidacloprid treatment and showed higher toxic that dimethoate treatment.

The observation at 120 and 144 HAA showed that nanoemulsion formulationa at $1 \%$ and $10 \%$ gave high mortality effect to aphids and showed not significantly different with the treatments of two synthetic insecticides. Based on the results, it can be stated that tobacco botanical insecticide in nanoemusion formulations were more effective than in crude extract formulations.

Based on the results of probit analysis, $\mathrm{LD}_{50}$ and $\mathrm{LD}_{90}$ values for each formulation were shown on Table 1 . The $\mathrm{LD}_{50}$ and $\mathrm{LD}_{90}$ values of tobacco crude extracts were higher than the nano emulsion formulation. The $\mathrm{LD}_{50}$ and $\mathrm{LD}_{90}$ values of crude extracts at $48 \mathrm{HAA}$ were $0.73 \%$ and $2.56 \%$, 
while of nano emulsion formulations were $0.14 \%$ and $1.69 \%$, respectively. This means that lower concentration is needed to control citrus aphids when using nano emulsion formulation of tobacco botanical insecticide

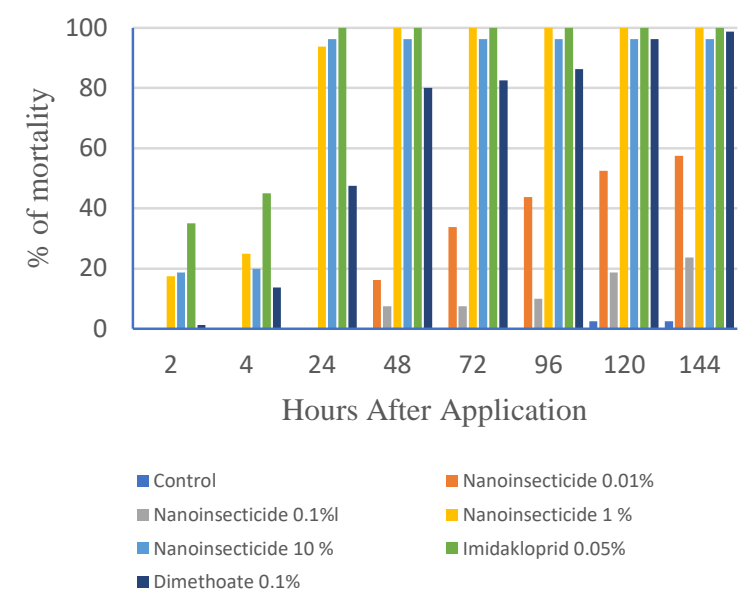

Figure 2 The mortality effect of nano emulsion of tobacco botanical insecticide on citrus aphids Aphis gossypii

Particle size of formulation affected the absorption of the pesticide into the target of insect's body. Smaller droplet particle size will be more effective than bigger ones. The nano formulation of insecticides was developed to increase the efficacy, efficiency and stability of the formulation and reduce the use of pesticides. The particle size of crude extracts was much larger than the size of the nano emulsion formulation (Table 2). The use of nanotechnology to reduce particle size of pesticide formulation to nano size is expected to increase the efficiency and effectiveness of pesticide application [22]. The particle size of tobacco nano emulsion formulation was $151.6 \mathrm{~nm}$, much smaller than the crude extract particle size which was $4059 \mathrm{~nm}$. The small particle size of formulation allowed easier and faster absorption into the cuticle of the insect.

The polydispersity index showed the homogeneity of the size distribution of the particles. The tobacco nano emulsion formulation showed a fairly uniform homogeneity of particle distribution as indicated by a PdI value of below 0.3 . Whereas for the crude extracts, the PdI value was larger which was 0.865 . The potential zeta value obtained from the measurement of plant-based insecticidal emulsions was to determine the degree of stability of the particles. Positive and negative values on the results indicated particle charge. In its category, if the zeta potential is more than 30 , the particle is in the stable category. In the results of measurements, the potential zeta value of tobacco nano emulsion formulation was -16.7 , indicating that the formulation was less stable compared to the tobacco crude extract with a potential zeta value of -45.9. Nano emulsion is a transparent, translucent emulsion system and is a water oil dispersion that is stabilized by a film layer of a surfactant or surfactant molecule. Droplet size is ranging from 50$1000 \mathrm{~nm}[23,24]$. The small nano emulsion droplet size makes the formula kinetic stable so as to prevent sedimentation and creeping during storage [25]. Nano emulsion with oil-in-water $(\mathrm{o} / \mathrm{w})$ emulsion system is also an alternative to increase the solubility and stability of bioactive components contained in oil [26].

Table $1 \mathrm{LD}_{50}$ and $\mathrm{LD}_{90}$ values of tobacco botanical insecticide on citrus aphids, A. gossypii

\begin{tabular}{|l|c|c|c|}
\hline Times observe & Materials & LD $_{\mathbf{5 0}}$ & LD $_{\mathbf{9 0}}$ \\
\hline \multirow{2}{*}{24 HAA } & Nano emulsion & 1.35 & 4.09 \\
& Crude extract & 2.43 & 10.78 \\
\hline \multirow{2}{*}{48 HAA } & Nano emulsion & 0.14 & 1.69 \\
& Crude extract & 0.73 & 2.65 \\
\hline \multirow{2}{*}{72 HAA } & Nano emulsion & 0.09 & 1.63 \\
& Crude extract & 0.69 & 2.47 \\
\hline \multirow{2}{*}{ 120 HAA } & Nano emulsion & 0.03 & 1.17 \\
& Crude extract & 0.10 & 2.01 \\
\hline \multirow{2}{*}{ 144 HAA } & Nano emulsion & 0.02 & 1.02 \\
& Crude extract & 0.06 & 1.67 \\
\hline
\end{tabular}

Table 2 Measurement results of botanical insecticide

\begin{tabular}{|l|c|c|c|}
\hline Material & Particle size (nm) & $\begin{array}{c}\text { Polydispersity } \\
\text { Index }\end{array}$ & $\begin{array}{c}\text { Zeta } \\
\text { Potensial }\end{array}$ \\
\hline Nanoemulsion of tobacco insecticide & 151.6 & 0.256 & -16.7 \\
\hline Crude extract of tobacco insecticide & 4059 & 0.865 & -45.9 \\
\hline
\end{tabular}


[10] S.J. Pangihutan, C.N. Rochman Y. Mulyaningsih, Daya insektisida ekstrak daun kipahit (Tithonia diversifolia (Hamsley) a. gray) dan tembelekan (Lantana camara 1.) terhadap hama gudang Callosobruchus maculatus F, J. Agronida 2(1) (2016) $1-9$

[11] E. Nabil, El-Wakeil, Botanical Pesticides and Their Mode of Action. Gesunde Pflanz. 65 (2013) 125149. DOI:https://doi.org/10.1007/s10343-0130308-3

\section{REFERENCES}

[1] M.E. Dwiastuti, A. Triwiratno, O. Endarto, S. Wuryantini, Yunimar. Pengenalan dan pengendalian hama dan penyakit tanaman jeruk. Balai Penelitian Tanaman Jeruk dan Buah Subtropika. Badan Litbang Pertanian. 2011

[2)] M.B. Isman, Botanical insecticides: for richer, for poorer. Pest. Manag. Sci. 64 (2008) 8-11

[3] A. Prakash, J. Rao, Botanical Pesticides in Agriculture. Boca Raton Florida. Louis Publishers. $1197,476 \mathrm{p}$

[4] G.W. Ware, Pesticides. Theory and application. Freeman, San Francisco, 1983, pp. 308

[5] J.M.R. Thacker, An introduction to arthropod pest control. Cambridge University Press, Cambridge, 2002, 343 p

[6] M.B. Isman, Botanical insecticides, deterrents, and repellents in modern agriculture and an increasingly regulated world. Annu. Rev. Entomol. 51 (2006) 45-66

[7] Harwanto, Bioaktivitas ekstrak limbah daun tembakau (Nicotiana tabacum 1.) sebagai insektisida nabati untuk ulat bawang merah Spodoptera exigua Hubner (Lepidoptera: Noctuidae). Disertasi. Program Pasca Sarjana Fakultas Pertanian Universitas Gadjah Mada Yogyakarta, 2012

[8] Harwanto, S. Wuryantini, O. Endarto, Yunimar. Teknologi bioprosesing insektisida botani yang bersumber dari metabolit sekunder yang dihasilkan tanaman. Laporan penelitian Balai Penelitian Tanaman Jeruk dan Buah Subtropika, 2015

[9] S. Wuryantini, Harwanto, R.A. Yudhistira, Identification of Bioactive Compounds and Insecticidal Potential of JC Citrus Peel Extract to Citrus Psyllid Diaphorina citri and Citrus Aphids Aphis gossypii. Proceeding The International Seminar on Tropical Horticulture, Horticulture for The Quality of Life Bogor, December 10th, 2018. 2019, pp. 62-70

[12] P.W.C. Green, R. Steven, Belmainb, A. Patrick, Ndakidemic, W. Iain, Farrella, C. Philip, Stevensona, Insecticidal activity of Tithonia diversifolia and Vernonia amygdalina, Ind. Crop. Prod. 110 (2017) 15-21

[13] P. Bussaman, P. Namsena, P. Rattanasena, A. Chandrapatya, Effect of Crude Leaf Extracts on Colletotrichum gloeosporioides (Penz.) Sacc. Hindawi, Publishing Corporation Psyche, (2012) 6, Article ID 309046, DOI:https://doi.org/10.1155/2012/309046

[14] P. Bussaman, C. Sa-uth, P. Rattanasena, A. Chandrapatya, Effect of crude plant extracts on Mushroom Mite, Luciaphorus sp. (Acari: Pygmephoridae). Psyche, (2012) 1-5. DOI:https:// doi.org/10.1155/2012/150958

[15] A.A. Osipitan, A.E. Oseyemi, Evaluation of the bio-insecticidal potential of some tropical plant extracts against termite (Termitidae: Isoptera) in Ogun State, Nigeria, J. Entomol. 9(5) (2012) 257 265. DOI:https://doi.org/103923/je.2012.257.265

[16] J.M. Mari, Efficacy of Different Plant Extracts Against Diamondback Moth, Plutella xylostella (L.) on Cauliflower. Proceedings of International Conference on Applied Life Sciences (ICALS 2012) Turkey, September 2012, pp. 10-12. 199-204

[17] H. Chhipa, Nanopesticide: Current Status and Future Possibilities. Mini Review. Agri. Res. Tech. 5(1) (2017) 1-4. DOI:https://doi.org/10.19080/ARTOAJ. 2017.05.555651

[18] H. Boumesteer, S. Dekkers, M.Y. Noordam, W.I. Hagens, A.S. Bulder, C. de Heer, S.E. ten Voorde, S.W. Wijnhoven, H.J. Marvin, A.J. Sipd, Review of health safety aspects of nanotechnologies in food production. Regul. Toxicol. Pharmacol. 53(1) (2008) 52-62. DOI:https://doi.org/10.1016/j.yrtph.2008.10.008

[19] LL. Bergeson, Nanosilver: US EPA's pesticide office considers how best to proceed. Environ. Qual. Manage. 19 (2010) 79-85 
[20] M. Gutiérrez, C. González, A. Maestro, I. Solè, C.M. Pey, J. Nolla, Nano-emulsions: New applications and optimization of their preparation. Current Opinion J. Colloid Interf. Sci. 13 (2008) 245-251.

DOI:https://doi.org/ 10.1016/j.cocis.2008.01.005.

[21] R. Voight, Buku Pelajaran Teknologi Ekstraksi, Diahlibahasakan oleh Soewandhi, S. N. Edisi 5, Gadjah Mada University Press, Yogyakarta, 1995

[22] H. Rahma, J. Trisno, R. Noveriza, S. Yuliani, Martinius, Reflin, Paket Teknologi Bakteri Perakaran Pemacu Pertumbuhan Tanaman dengan Pupuk Kandang dan Nanopestisida Serai Wangi untuk Pengendalian Penyakit Vsd Tanaman Kakao. Laporan Akhir Kerjasama Penelitian, Pengkajian, Dan Pengembangan Pertanian Strategis Litbang Pertanian, 2017

[23] K.S. Soppimath, T.M. Aminabhavi, A.R. Kulkarni, W.E. Rudzinski, Biodegradable polymeric nanoparticles as drug delivery devices. J. Control. Release, 70 (2001) 1-20

[24] F. Shakeel, S. Baboota, A. Ahuja, J. Ali, M.S. Faisal, S. Shafiq, Stability evaluation of celecoxib nanoemulsion containing Tween 80. Thai. J. Pharm. Sci. 32 (2008) 4-9

[25] C. Solans, P. Izquierdo, J. Nolla, N. Azemar, M.J. Garcia-Celma, Nanoemulsions. J. Colloid Interf. Sci. 10(3-4) (2005): 102-110

[26] S. Yuliasari, Hamdan, Karakterisasi nanoemulsi minyak sawit merah yang disiapkan dengan high pressure homogenizer. Prosiding InSiNas. 2008, pp. $25-28$ 